\title{
Mercury Distribution and Reactivity in Waters of a Subtropical Coastal Lagoon, Sepetiba Bay, SE Brazil
}

\author{
Luiz D. Lacerda* ${ }^{* a, b}$, Rozane V. Marins ${ }^{a, c}$, Heloísa H. M. Paraquetti ${ }^{a}$, \\ Stephane Mounier ${ }^{b}$, Jean Benaim ${ }^{b}$ and Dominique Fevrier \\ ${ }^{a}$ Departamento de Geoquímica, Universidade Federal Fluminense, 24020-007, Niterói - RJ - Brazil \\ ${ }^{b}$ Department de Chimie, Lab. RCMO, Universite de Toulon et du Var, BP 132/83157 - La Garde - France \\ ${ }^{\mathrm{c}}$ Departamento de Geologia, Universidade Federal do Ceará, 60455-970, Fortaleza - CE, Brazil
}

\begin{abstract}
As concentrações de $\mathrm{Hg}$ total e reativo, de carbono orgânico dissolvido (COD) e carbono orgânico particulado (COP) foram medidas em diferentes massas d'água na Baía de Sepetiba, SE do Brasil, com o objetivo de avaliar mudanças na reatividade do $\mathrm{Hg}$ ao longo do gradiente estuarino. As concentrações de $\mathrm{Hg}$ reativo foram mais baixas em águas da baía franca $\left(0,09 \pm 0,06 \mathrm{ng} \mathrm{L}^{-1}\right)$, seguidas pelas águas influenciadas por rios $\left(0,19 \pm 0,06 \mathrm{ng} \mathrm{L}^{-1}\right)$, e pelas de manguezais $(0,29 \pm$ $\left.0,02 \mathrm{ng} \mathrm{L}^{-1}\right)$. As concentrações de $\mathrm{Hg}$ total foram menores em águas da baía franca $(0,38 \pm 0,20$ $\left.n g \mathrm{~L}^{-1}\right)$, seguidas pelas águas de manguezais $\left(0,56 \pm 0,01 \mathrm{ng} \mathrm{L}^{-1}\right)$, e foram maiores nas águas influenciadas por rios $\left(0,99 \pm 0,29 \mathrm{ng} \mathrm{L}^{-1}\right)$. O percentual de $\mathrm{Hg}$ reativo em relação à concentração total foi menor nas águas influenciadas por rios $(20,7 \%)$, seguidas pelas de águas da baía franca $(31,2 \%)$, e foram maiores nas águas de manguezais $(53,2 \%)$. O percentual de $\mathrm{Hg}$ reativo em relação à concentração total apresentou significativa correlação inversa com as concentrações de $\mathrm{Hg}$ total. Nenhuma correlação significativa foi encontrada entre as concentrações de $\mathrm{Hg}$ e a salinidade, o COP e o pH. Entretanto, as concentrações de $\mathrm{Hg}$ reativo apresentaram uma correlação positiva, significativa com o COD, mostrando que o controle da reatividade do $\mathrm{Hg}$ e, eventualmente, de sua biodisponibilidade na Baía de Sepetiba, deve-se principalmente a formação de complexos com a matéria orgânica dissolvida.
\end{abstract}

A survey of the reactive and total $\mathrm{Hg}$ concentrations in surface waters and of the quantity of particulate organic carbon (POC) and dissolved organic carbon (DOC), were performed along a transect from the major rivers mouths and mangrove dominated areas to the open bay waters of Sepetiba Bay, SE Brazil. The objective of the survey was to evaluate changes in $\mathrm{Hg}$ reactivity during the transport along the estuarine gradient. Reactive $\mathrm{Hg}$ concentrations were lowest in open bay waters, $\left(0.09 \pm 0.06 \mathrm{ng} \mathrm{L}^{-1}\right)$, followed by river influenced waters $\left(0.19 \pm 0.06 \mathrm{ng} \mathrm{L}^{-1}\right)$, and mangrove $\left(0.29 \pm 0.02 \mathrm{ng} \mathrm{L}^{-1}\right)$. Total $\mathrm{Hg}$ concentrations were lowest in open bay $(0.38 \pm 0.20 \mathrm{ng}$ $\left.\mathrm{L}^{-1}\right)$, followed by mangrove waters $\left(0.56 \pm 0.01 \mathrm{ng} \mathrm{L}^{-1}\right)$, and river influenced waters $(0.99 \pm 0.29$ $\left.\mathrm{ng} \mathrm{L}^{-1}\right)$. The percentages of reactive $\mathrm{Hg}$ relative to the total $\mathrm{Hg}$ concentrations were lowest in river influenced waters, $(20.7 \%)$, followed by open bay waters (31.2\%), and mangrove waters $(53.2 \%)$. The percent of reactive $\mathrm{Hg}$ to the total $\mathrm{Hg}$ concentrations showed a significant negative correlation with the total $\mathrm{Hg}$ concentrations following a potential equation. No relationship between reactive $\mathrm{Hg}$ concentrations and $\mathrm{POC}$, salinity or $\mathrm{pH}$ were found, however, reactive $\mathrm{Hg}$ correlates significantly with DOC, suggesting that organo-complexes, rather than chloro-complexes, are the major controllers of $\mathrm{Hg}$ reactivity, and eventually bioavailability in Sepetiba Bay.

Keywords: mercury, Sepetiba bay, speciation, waters

\section{Introduction}

Mercury presents a non-conservative behavior during estuarine mixing, due to its particularly high reactivity. Along estuarine gradients, $\mathrm{Hg}$ may undergo strong speciation changes, resulting in different biovailability ${ }^{1,2}$. Thus, the study of $\mathrm{Hg}$ concentrations and of its variability in coastal waters has received large attention due to its direct relationship with fish $\mathrm{Hg}$ concentrations. Under estuarine conditions, $\mathrm{Hg}$ availability to biota may change due to changes in salinity regime ${ }^{3}$, redox potential and sulfide concentration ${ }^{4}$, properties of the dissolved organic matter ${ }^{5}$, photochemical reactions ${ }^{6}$, and sediment ressuspen-sion ${ }^{7}$. Previous studies on the partitioning of $\mathrm{Hg}$ in surface estuarine waters have shown that from $50 \%$ to $80 \%$ of 
the total $\mathrm{Hg}$ concentration at the upper portion of the estuarine gradient are strongly bound to organic matter and/or suspended particles $8,9,10,11$. This characteristic may result in lower bioavailability and more efficient removal from the water column under estuarine conditions. However, during the transport through the estuarine gradient changes in the composition of suspended matter may occur, as well as degradation of particulate (POC) and dissolved (DOC) organic carbon, eventually releasing reactive $\mathrm{Hg}$ to the water column.

Changes in the availability of $\mathrm{Hg}$ may be more important to control $\mathrm{Hg}$ levels in fish than the total $\mathrm{Hg}$ content in the water column. In the Sepetiba Bay estuarine complex, an important fisheries area at the Rio de Janeiro coast, this may be the case. A recent survey on $\mathrm{Hg}$ content in the snapper Micropogonias furnieri ${ }^{12}$ showed highest $\mathrm{Hg}$ concentrations in fish collected far from major rivers, which are the principal source of $\mathrm{Hg}$ to the Bay ${ }^{13}$. The explanation for this apparent paradox may be the increase in $\mathrm{Hg}$ reactivity along the estuarine gradient, where $\mathrm{Hg}$ faces different physico-chemical environments from different water masses, notwithstanding the decrease in total $\mathrm{Hg}$ dissolved concentrations.

To test this hypothesis, a survey of the reactive and total $\mathrm{Hg}$ concentrations in surface waters and of the quantity of POC and DOC were performed along a transect from the major river mouths to the open bay waters of Sepetiba Bay. Also, since about $35 \%$ of the Bay's coastline is covered by mangrove ecosystems, an environment with distinct water chemistry, surface waters from a mangrove dominated inlet were sampled.

The objective of the survey was to evaluate changes in $\mathrm{Hg}$ reactivity and organic matter characteristics during the transport along the estuarine gradient, from river mouths and from mangrove, to open bay waters, and eventually explain the results found on fish $\mathrm{Hg}$ concentrations ${ }^{12}$.

\section{Material and Methods}

\section{Environmental setting of Sepetiba Bay}

Sepetiba Bay is a semi-enclosed water body with 447 $\mathrm{km}^{2}$ of area, average depth of $6.0 \mathrm{~m}$ and tidal range of less than $2.0 \mathrm{~m}$. The Bay is approximately located at latitude $23^{0}$ $\mathrm{S}$ and longitude $44^{0} \mathrm{~W}$, about $60 \mathrm{~km}$ south of Rio de Janeiro city (Figure 1). The region is under a hot-humid tropical climate, with mean annual precipitation ranging from 1,400 $\mathrm{mm}$ to $2,500 \mathrm{~mm}$, depending on the location along the coast. Nine rivers draining the quaternary plain at the northeastern coast of the Bay are responsible for almost the totality of freshwater inputs, reaching an annual flow of 7.6 million $\mathrm{m}^{3}$. Annual atmospheric precipitation over Sepetiba Bay

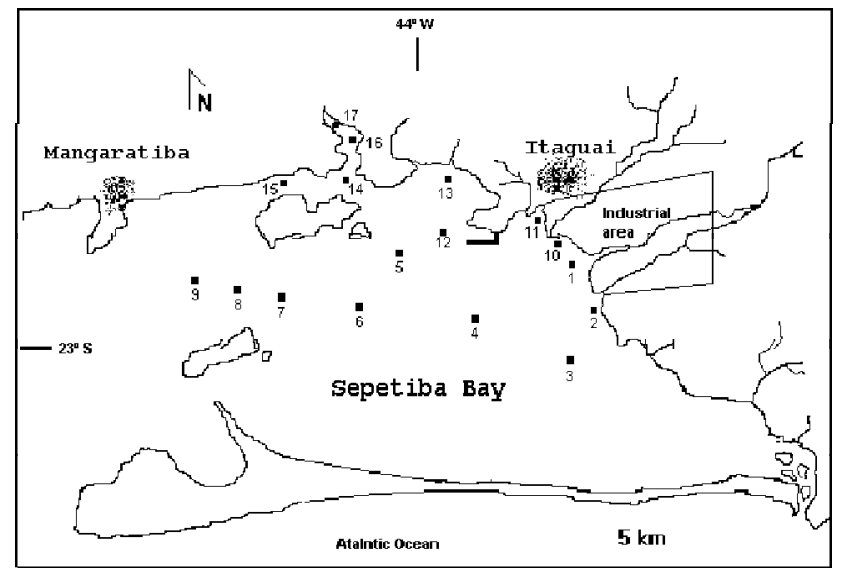

Figure 1. Sampling sites location and major geographical features of Sepetiba Bay, SE Brazil.

( 0.5 to $\left.10 \times 10^{7} \mathrm{~m}^{3} \mathrm{yr}^{-1}\right)$ equals and may even surpass the fluvial inputs, increasing the importance of atmospheric derived pollutants from local smelters ${ }^{14,15}$.

The lowlands of the eastern coast of Sepetiba Bay, with good transport facilities, cheap and ample land, good fresh water supply and low population density, became interesting to industrial development, further facilitated by the building in the late 70's of large harbor facilities. Population of the bay has raised from 600,000 people in 1978 to 1.2 million, mostly concentrated along the northeastern shore as a result of the industrial growth. This fast and unplanned development resulted in high contamination of the bay in direct conflict with the necessity of environmental conservation and the sustainable utilization of the bay's natural resources ${ }^{15}$.

Most trace metal loads, including $\mathrm{Hg}$, to the bay are from fluvial inputs associated with suspended particles ${ }^{13,14,15}$. Terrigenous matter are transported through surface currents and preferentially deposited along the NE shore of the bay, forming extensive mud flats covered by mangroves and salt marshes.

\section{Sampling and analysis}

All sampling and analytical ware were pre-cleaned according to accepted protocols ${ }^{8}$. In two cruises (November, 1997 and March, 1998) surface water samples were collected by divers with $0.5 \mathrm{~L}$ pre-cleaned Teflon bottles and Teflon gloved hands avoiding the surface microlayer, following careful procedures to avoid sampling contamination ${ }^{7}$. Cruises lasted 2 to 4 hours during neap tides only. Care was taken to avoid alterations in water chemistry due to tidal change by not sampling during spring tide and sampling river and mangrove waters during the ebb period and open bay waters during flood periods. The sampling bottles were rinsed three times with the local water 
before being filled. The bottles were capped while immersed in the water to prevent contact with the atmosphere between sampling and handling. Bottles were double bagged in acid-washed plastic bags and transported in an ice box to the laboratory. Two samples from each of a total of seventeen (17) stations were collected for $\mathrm{Hg}$ analyses along the estuarine gradient of Sepetiba Bay (Figure 1). All samples were immediately analyzed after collection (within 4 to 6 hours maximum) $2,16,17,18,19$. During the period between sampling and analysis samples were kept in an ice box.

Unfiltered, non-acidified, sub-samples $(250 \mathrm{~mL})$ were analyzed for reactive $\mathrm{Hg}$ considered here as the fraction of the total $\mathrm{Hg}$ concentration that is reduced and therefore released from solution after the addition of $1.0 \mathrm{~mL}$ of acidic (2.6 mol L-1 $\mathrm{HCl}) 1.0 \% \mathrm{SnCl}_{2}$ solution ${ }^{16,17}$. This fraction includes mostly ionic $\left(\mathrm{Hg}^{2+}\right)$ plus dissolved gaseous $\mathrm{Hg}$ (DGM), but also the $\mathrm{Hg}$ fraction weakly bound to inorganic and organic complexes ${ }^{2,16,17}$. However, it does not include $\mathrm{Hg}$ leacheable from particulate matter ${ }^{18}$. Since we did not acidify the samples prior to analysis, our reactive $\mathrm{Hg}$ fraction does not compare with the reactive $\mathrm{Hg}$ fractions typically reported in literature which used acidified samples ${ }^{18,19}$.

Total $\mathrm{Hg}$ was determined after oxidation with bromine monochloride $(\mathrm{BrCl})$. After oxidation, $0.1 \mathrm{~mL}$ of $1 \%$ ascorbic acid solution was used to reduce the excess $\mathrm{BrCl}$; this was followed by a reduction with the same $\mathrm{SnCl}_{2}$ solution used for reducing the reactive $\mathrm{Hg}$ fraction ${ }^{20}$. Total $\mathrm{Hg}$ includes all dissolved $\mathrm{Hg}$ species strongly bound to soluble inorganic and organic complexes, and $\mathrm{Hg}$ weakly bound to suspended particles.

The $\mathrm{Hg}^{0}$ resulting from the reduction reaction for water samples was purged from the sample with $\mathrm{Hg}$-free Argon, at a flow rate of $40 \mathrm{~mL} \mathrm{~min}^{-1}$, for $3 \mathrm{~min}$, and collected on a Au wool trap connected to the outlet of the reaction vessel. Two Au traps in the gas line stripped any $\mathrm{Hg}$ from the carrier gas. All connecting tubing was made of Teflon with glass-Teflon connections made of clean silicone tubing. Mercury determination was performed, in a Tekran Model 2500 Cold Vapor Atomic Fluorescence Spectrophotometer. Under the operational conditions described, the analytical detection limit of the method, based on three standard deviations of the average $\mathrm{Hg}$ concentrations of the reagents blank, was $0.02 \mathrm{ng}$ $\mathrm{L}^{-1}$. All samples were analyzed in duplicate. Differences between duplicates remained below $15 \%$ for all stations.

From each station during the second cruise (station 10 through 17), $250 \mathrm{~mL}$ sub-samples were collected for POC and DOC analysis. Particulate organic carbon (POC) were determined after filtration through a Millipore filter $0.45 \mu \mathrm{m}$ and POC concentrations determined in an Auto analyzer.
Dissolved organic carbon (DOC) was analyzed in the filtered sample with a Dorhman DC 80, a wet oxidation analyzer. In this case an aliquot of $4.0 \mathrm{~mL}$ was sampled from the $250 \mathrm{~mL}$ bottle. Samples were acidified and purged immediately prior to the injection of $\mathrm{CO}_{2}$ - free nitrogen for inorganic carbon removal. Total oxidation was performed by simultaneous action of UV-irradiation and persulfate oxidation.

During the sampling, some major physical and chemical parameters were also measured in situ. Salinity was determined using a SHIBUYA refratometer whereas $\mathrm{pH}$ and temperature, were measured with a DIGIMED $\mathrm{pH}$ meter, with a combined glass electrode. Precision of such filed determinations was 0.1 units.

\section{Results and Discussion}

Mercury concentrations of all samples and organic carbon concentrations of the second cruise samples are presented in Table 1. Reactive $\mathrm{Hg}$ concentrations were lowest in open bay waters, ranging from 0.04 to $0.22 \mathrm{ng} \mathrm{L}^{-1}$ (average $0.09 \pm 0.06 \mathrm{ng} \mathrm{L}^{-1}$ ), followed by river influenced waters, ranging from 0.13 to $0.26 \mathrm{ng} \mathrm{L}^{-1}$ (average $0.19 \pm 0.06 \mathrm{ng} \mathrm{L}^{-1}$ ). Mangrove waters presented the highest reactive $\mathrm{Hg}$ concentrations, ranging from 0.28 to $0.31 \mathrm{ng} \mathrm{L}^{-1}$ (average $0.29 \pm 0.02 \mathrm{ng} \mathrm{L}^{-1}$ ). Total $\mathrm{Hg}$ concentrations were also lowest in open bay waters, ranging from 0.08 to $0.66 \mathrm{ng} \mathrm{L}^{-1}$ (average $0.38 \pm 0.20 \mathrm{ng} \mathrm{L}^{-1}$ ), followed by mangrove waters, ranging from 0.55 to $0.56 \mathrm{ng} \mathrm{L}^{-1}$ (average $0.56 \pm 0.01 \mathrm{ng} \mathrm{L}^{-1}$ ). River influenced waters presented the highest total $\mathrm{Hg}$ concentrations, ranging from 0.44 to $1.30 \mathrm{ng} \mathrm{L}^{-1}$ (average $0.99 \pm$ $0.29 \mathrm{ng} \mathrm{L}^{-1}$ ). The percentage of reactive $\mathrm{Hg}$ relative to the total $\mathrm{Hg}$ concentrations were lowest in river influenced waters, with an average of $20.7 \%$, followed by open bay waters, with an average of $31.2 \%$. Mangrove waters presented the highest percentage of reactive $\mathrm{Hg}$ relative to the total $\mathrm{Hg}$ concentrations (average 53.2\%). Table 2 shows the mean and standard deviations of $\mathrm{Hg}$ concentrations in Sepetiba Bay waters.

Figure 2 summarizes graphically the results on the $\mathrm{Hg}$ distribution in the three different water masses. Reactive $\mathrm{Hg}$ concentration is the best parameter to differentiate water masses, separating clearly the three groups of samples at a $\mathrm{P}<0.05$ level. Total $\mathrm{Hg}$ concentrations could only differentiate river influenced water masses $(\mathrm{P}<0.05)$, but not open bay waters from mangroves, due to the large variability of total $\mathrm{Hg}$ concentrations in open bay waters. On the other hand, the large variability found in the relative concentrations of reactive $\mathrm{Hg}$ in open bay waters could not clearly differentiate them from river influenced or mangrove waters. 
Table 1. Mercury concentrations in waters of Sepetiba Bay. Concentrations of DOC and POC are from samples collected during the $2^{\text {nd }}$ cruise only.

\begin{tabular}{|c|c|c|c|c|c|c|c|c|c|}
\hline Cruise & Station & $\begin{array}{l}\text { Temp } \\
\left({ }^{\circ} \mathrm{C}\right)\end{array}$ & $\mathrm{pH}$ & Salinity & $\begin{array}{c}\text { Reactive } \\
\mathrm{Hg}\left(\mathrm{ng} \mathrm{L}^{-1}\right)\end{array}$ & $\begin{array}{l}\text { Total Hg } \\
\left(n g L^{-1}\right)\end{array}$ & $\begin{array}{c}\text { Reactive } \\
\mathrm{Hg}(\%)\end{array}$ & $\begin{array}{c}\text { DOC } \\
\left(\mathrm{mg} \mathrm{L}^{-1}\right)\end{array}$ & $\begin{array}{c}\text { POC } \\
\left(\mathrm{mg} \mathrm{L}^{-1}\right)\end{array}$ \\
\hline \multirow[t]{9}{*}{$1^{\mathrm{st}}$} & 1 (river-influence) & 24 & 7.8 & 24 & 0.13 & 1.01 & 12.9 & - & - \\
\hline & 2 (river-influence) & 24 & 6.8 & 13 & 0.14 & 0.44 & 31.8 & - & - \\
\hline & 3 (sea) & 24 & 7.9 & 34 & 0.06 & 0.21 & 28.6 & - & - \\
\hline & 4 (sea) & 24 & 7.9 & 34 & 0.06 & 0.08 & 75.0 & - & - \\
\hline & 5 (sea) & 24 & 7.1 & 32 & 0.06 & 0.33 & 18.2 & - & - \\
\hline & 6 (sea) & 24 & 8.0 & 35 & 0.05 & 0.26 & 19.2 & - & - \\
\hline & 7 (sea) & 24 & 8.0 & 36 & 0.04 & 0.48 & 8.3 & - & - \\
\hline & 8 (sea) & 24 & 8.0 & 35 & 0.06 & 0.66 & 9.1 & - & - \\
\hline & 9 (sea) & 24 & 8.0 & 35 & 0.08 & 0.48 & 16.7 & - & - \\
\hline \multirow[t]{8}{*}{$2^{\text {nd }}$} & 10(river-influence) & 24 & 7.6 & 30 & 0.16 & 1.10 & 14.5 & 1.7 & 0.7 \\
\hline & 11(river-influence) & 24 & 7.6 & 20 & 0.25 & 1.00 & 25.0 & 2.1 & 1.2 \\
\hline & 12 (sea) & 24 & 7.6 & 32 & 0.22 & 0.65 & 33.8 & 1.9 & 0.6 \\
\hline & 13(river-influence) & 24 & 7.5 & 30 & 0.26 & 1.10 & 23.6 & 2.2 & 1.1 \\
\hline & 14(river-influence) & 24 & 7.6 & 30 & 0.21 & 1.30 & 16.2 & 1.7 & 0.5 \\
\hline & 15 (sea) & 24 & 8.2 & 32 & 0.18 & 0.25 & 72.0 & 1.9 & 1.7 \\
\hline & 16 (mangrove) & 24 & 7.4 & 35 & 0.28 & 0.55 & 50.9 & 5.8 & 3.5 \\
\hline & 17 (mangrove) & 24 & 7.2 & 34 & 0.31 & 0.56 & 55.4 & 3.9 & 2.8 \\
\hline
\end{tabular}

Table 2. Mean and standard deviations and range of $\mathrm{Hg}$ concentrations in different water masses from Sepetiba Bay, SE Brazil. $(\mathrm{n}=$ number of samples collected and analysed in the respective water mass)

\begin{tabular}{|c|c|c|c|}
\hline $\mathrm{Hg}$ concentrations & $\begin{array}{l}\text { Open bay waters } \\
(\mathrm{n}=18)\end{array}$ & $\begin{array}{l}\text { River influenced waters } \\
\qquad(\mathrm{n}=12)\end{array}$ & $\begin{array}{l}\text { Mangrove waters } \\
\qquad(\mathrm{n}=4)\end{array}$ \\
\hline Reactive $\mathrm{Hg}\left(\mathrm{ng} \mathrm{L}^{-1}\right)$ & $0.09 \pm 0.06$ & $0.19 \pm 0.06$ & $0.29 \pm 0.02$ \\
\hline Total $\mathrm{Hg}\left(\mathrm{ng} \mathrm{L}^{-1}\right)$ & $0.38 \pm 0.20$ & $0.99 \pm 0.29$ & $0.56 \pm 0.01$ \\
\hline Reactive $\mathrm{Hg}$ as $\%$ of the total & $31.2 \pm 25.3$ & $20.7 \pm 7.30$ & $53.2 \pm 3.20$ \\
\hline
\end{tabular}
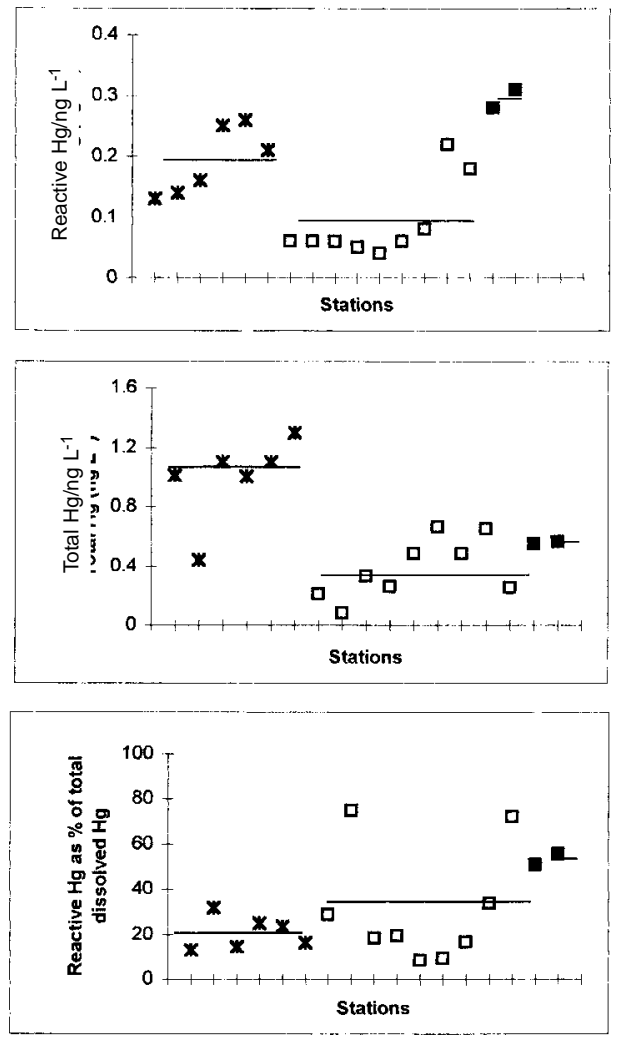

Figure 2. Distribution of $\mathrm{Hg}$ concentrations in the different water masses of Sepetiba Bay, SE Brazil. ( $\square$ - river influenced waters; $\square$ - open bay waters; - mangrove waters; * river influenced waters). Horizontal lines represent average concentrations.
Total and reactive $\mathrm{Hg}$ concentrations were highest close to rivers mouths, decreasing toward the open bay area. This is due to the high rivers water $\mathrm{Hg}$ content which has been shown to reach up to 10 times the concentrations measured in the bay ${ }^{13}$. These highest $\mathrm{Hg}$ concentrations close to rivers mouths may also result from frequent dredging for harbor maintenance and the lower depths of these stations and may probably reflect ressuspension of bottom sediments, which typically present $\mathrm{Hg}$ contents ranging from 80 to $140 \mathrm{ng} \mathrm{g}^{-1}$ in this sector of the Bay ${ }^{13}$. Similarly, at Narrangasset Bay ${ }^{11}$, a highly impacted coastal area, unfiltered water $\mathrm{Hg}$ concentrations decreased from fluvial influenced stations to open bay stations. Total $\mathrm{Hg}$ concentrations at Narragansset Bay decreased from 30.0 to $7.2 \mathrm{ng} \mathrm{L}^{-1}$ along this gradient, whereas reactive $\mathrm{Hg}$ concentrations decreased from 3.7 to $1.1 \mathrm{ng} \mathrm{L}^{-1}$. However, as in Sepetiba Bay, the percentage of reactive $\mathrm{Hg}$ relative to the total $\mathrm{Hg}$ concentrations also increased seaward ${ }^{11}$.

The total $\mathrm{Hg}$ concentrations found in Sepetiba Bay are lower than in other coastal areas with significant rivers inputs and point sources of $\mathrm{Hg}$. For example, total $\mathrm{Hg}$ concentrations ranged from 2.03 to $6.75 \mathrm{ng} \mathrm{L}^{-1}$ in the Adriatic Sea and was higher close to rivers mouths ${ }^{7}$, due to inputs from the mineralized region of Idria and the effluents of a chlor-alkali plant. In inshore marine waters of Australia, total $\mathrm{Hg}$ concentration average $15.0 \mathrm{ng} \mathrm{L}^{-1}$, but may increase 2 to 4 
times at strongly contaminated sites ${ }^{21}$. In 12 coastal lagoons ${ }^{17}$ of Rio de Janeiro, total $\mathrm{Hg}$ ranged from 7.3 to $57.0 \mathrm{ng} \mathrm{L}^{-1}$. The lower values from Sepetiba Bay are due to the absence of $\mathrm{Hg}$ point sources in Sepetiba Bay basin, which receives this pollutant from atmospheric deposition and runoff from soils ${ }^{13,22}$. On the other hand the values observed compare well with other coastal areas receiving $\mathrm{Hg}$ from diffuse sources only. In the Florida Everglades ${ }^{6}$, for example, total $\mathrm{Hg}$ concentrations ranged from 1.8 to $2.55 \mathrm{ng} \mathrm{L}^{-1}$.

When compared to open ocean waters $8,18,19,23$, where total $\mathrm{Hg}$ concentrations generally range from 0.1 to $0.4 \mathrm{ng} \mathrm{L}^{-1}$, Sepetiba Bay waters showed total $\mathrm{Hg}$ concentrations 2 to 13 times higher, confirming the importance of anthropogenic sources to the region. On the other hand, unfiltered reactive $\mathrm{Hg}$ in the North Atlantic surface waters average about $0.19 \mathrm{ng} \mathrm{L}^{-1}$, whereas total $\mathrm{Hg}$ averaged about $0.31 \mathrm{ng} \mathrm{L}^{-1}$. The percentage of reactive $\mathrm{Hg}$ relative to total concentrations reached $61 \%$ and was inversely correlated with total $\mathrm{Hg}$ concentrations ${ }^{23}$. Reactive $\mathrm{Hg}$ concentrations in open bay waters of Sepetiba Bay are similar or slightly lower than in the open ocean. However, mangrove waters and, to a lesser extent river influenced waters are, in general, higher than those reported for open ocean waters. The greater importance of the reactive fraction in coastal waters relative to the open ocean is probably related to the higher DOC concentrations in coastal areas, particularly in estuaries. Fitzgerald \& Lyons ${ }^{5}$ reported 50$60 \%$ of dissolved $\mathrm{Hg}$ in coastal waters as associated with organic matter. Andren \& Harris ${ }^{3}$ reported that dissolved $\mathrm{Hg}$ at the Mississippi and the Everglades estuarine areas is associated with DOC. In the present study, no relationship between reactive $\mathrm{Hg}$ concentrations and $\mathrm{POC}$, salinity or $\mathrm{pH}$ were found. However, reactive $\mathrm{Hg}$ correlates significantly with DOC concentrations (Figure 3), confirming the importance of this parameter in increasing $\mathrm{Hg}$ reactivity. The highest reactive $\mathrm{Hg}$ concentrations obtained from the mangrove stations samples, where maximum DOC was also observed, support this hypothesis.

The percent of reactive $\mathrm{Hg}$ to the total $\mathrm{Hg}$ concentrations showed a significant negative correlation with the total $\mathrm{Hg}$ concentrations $(r=-0.956)$. The relationship between these parameters followed a potential equation (Figure 4) with highest percentages, up to $75 \%$ of the total concentration, occurring where lowest total $\mathrm{Hg}$ content was present (0.08 ng L $\left.{ }^{-1}\right)$. Previous results from total digestion of rivers and estuarine waters from Sepetiba Bay showed that bromine chloride oxidation was unable to release all $\mathrm{Hg}$ present in water, suggesting that part of the $\mathrm{Hg}$ present was associated with clastic material, since aqua regia extraction resulted in higher $\mathrm{Hg}$ content ${ }^{13,24}$. In open Bay areas, deposition of suspended matter affect mostly the clastic material leaving

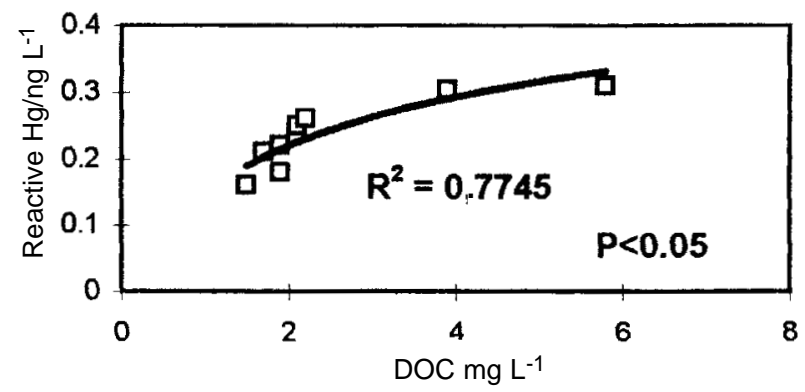

Figure 3. Relationship between dissolved organic carbon (DOC) and reactive $\mathrm{Hg}$ concentrations in waters of Sepetiba Bay, during the second cruise.
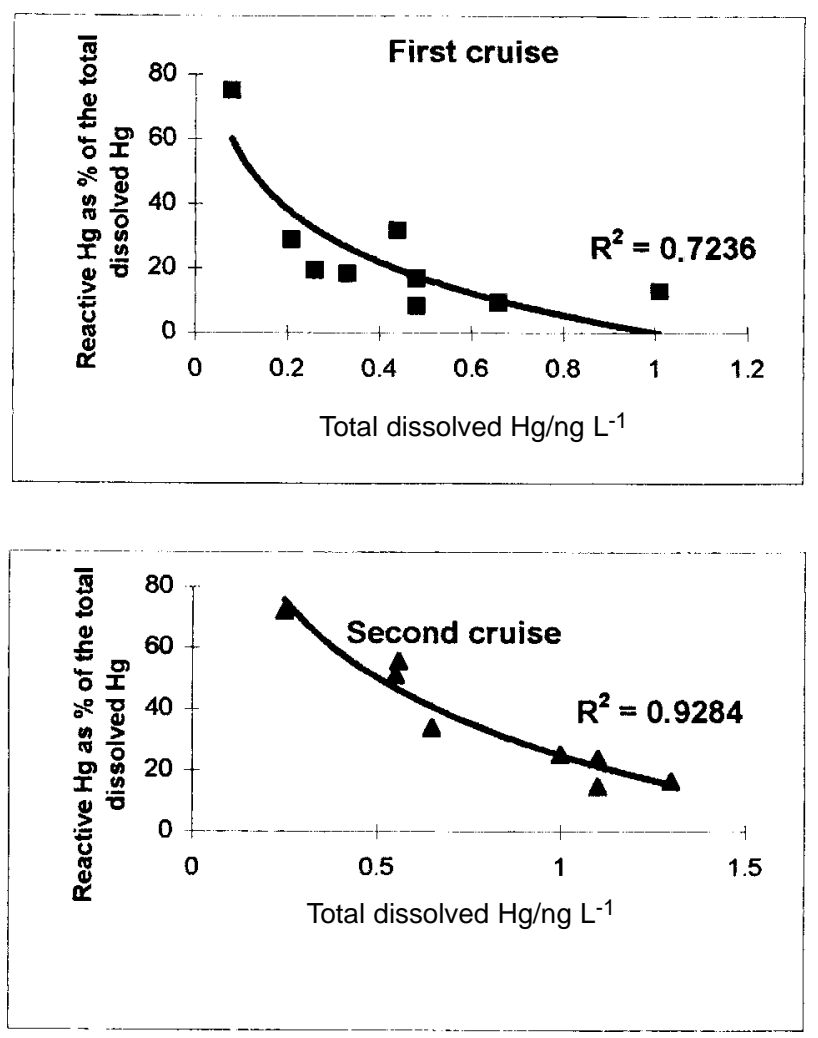

Figure 4. Relationship between total $\mathrm{Hg}$ concentrations and reactive $\mathrm{Hg}$ as percentage of the total $\mathrm{Hg}$ concentrations in Sepetiba Bay, SE Brazil.

mostly reactive $\mathrm{Hg}$. Mercury is not readily exchangeable from POC in the transition between freshwater to sea water ${ }^{3}$. Therefore, the decrease in total concentrations can be due to the scavenging of clastic particulate matter ${ }^{25}$. Thus, the relationship found between the percentage of reactive $\mathrm{Hg}$ and the total dissolved $\mathrm{Hg}$ may be due to the deposition of suspended matter close to rivers mouths and the predominance of ionic and soluble organic- $\mathrm{Hg}$ in open bay waters relative to rivers and estuarine waters. This mechanism was suggested to explain the increasing reactive $\mathrm{Hg}$ concentrations seaward at Narrangasset Bay, by Vandal and Fitzgerald $^{11}$. 


\section{Conclusions}

Mercury behavior in coastal areas is somewhat unusual, compared to most other heavy metals, due to the diversity of dissolved and particulate $\mathrm{Hg}$ species present in the water column. A preliminary budget for $\mathrm{Hg}$ in Sepetiba Bay ${ }^{26}$ concluded that about $15 \%$ of the total $\mathrm{Hg}$ entering the Bay is retained within the Bay sediments. At Haifa Bay ${ }^{27}$, this figure reaches only $10 \%$, whereas at Narrangasset Bay ${ }^{11}$, sediment retention reached $50 \%$. These mass balance studies highlight the importance of the $\mathrm{Hg}$ present in the water column in opposition to the $\mathrm{Hg}$ buried in sediments, as the major component of the $\mathrm{Hg}$ biogeochemical cycling in coastal areas.

The lack of correlation between $\mathrm{Hg}$ concentrations and salinity and the significant correlation between reactive $\mathrm{Hg}$ and DOC found in Sepetiba Bay waters suggest that organocomplexes, rather than chloro-complexes, are the major controllers of $\mathrm{Hg}$ reactivity, and eventually bioavailability in coastal waters. Thiol groups are most likely involved in the process, and the highest reactivity of $\mathrm{Hg}$ in mangrove waters, typically enriched in dissolved organo-sulfur compounds, confirms this hypothesis. Thus, the increasing reactivity of $\mathrm{Hg}$ seaward explains the relatively high $\mathrm{Hg}$ concentrations reported for fish caught in those areas.

\section{Acknowledgements}

This work was supported by the Conselho Nacional de Desenvolvimento Científico e Tecnológico (CNPq), Fundação de Amparo à Pesquisa do Estado do Rio de Janeiro (FAPERJ). This study is part of a bi-lateral cooperation between the CNPq (Brazil) and Conseil Nacional de Recherches Scientifique (CNRS), France. Thanks are also due to the Université de Toulon et du Var for providing support for a sabbatical leave at Toulon to one of the authors (LDL). RVM received a RD grant from CNPq.

\section{References}

1. Stordal, M. L.; Gill, G. A.; Wen, L. S.; Santschi, P.H. Limnol. Oceanogr. 1996, 41, 52.

2. Coquery, M.; Cossa, D.; Sanjuan, J. Mar. Chem. 1997, $58,213$.

3. Andren, A.W.; Harris, R. C. Geochim. Cosmochim. Acta 1975, 39, 1253.

4. Bjornberg, A.; Hakanson, L.; Lundberg, K. Environm. Pollut. 1988, 49, 53.
5. Fitzgerald, W. F.; Lyons, W. B. Nature 1973, 242, 452.

6. Krabbenhoft, D. P.; Hurley, J. P.; Olson, M. L.; Cleckner, L. B. Biogeochemistry 1998, 40, 311.

7. Ferrara, R.; Maserti, B.E. Mar. Chem. 1992, 38, 237.

8. Guentzel, J. L.; Powell, R. T.; Landing, W. M.; Mason, R. P. Mar. Chem. 1996, 55, 177.

9. Cossa, D.; Gobeil, C.; Courau, P. Estuar. Coast. Shelf Sci. 1988, 20, 289.

10. Leermakers, M.; Meuleman, G.; Baeyens, N. Water Air Soil Pollut. 1995, 80, 641.

11. Vandal, G.M.; Fitzgerald, W.F. Water Air Soil Pollut. 1995, 80, 679 .

12. Kherig, D. Concentração de Mercúrio em Corvinas (Micropogon furnierii) do Litoral do Estado do Rio de Janeiro. Msc Thesis, Universidade Católica, Rio de Janeiro, 1995.

13. Marins, R.V.; Lacerda, L. D.; Paraquetti, H. H. M.; Paiva, E.C.; Villas Boas, R. C. Bull. Environm. Contam. Toxicol. 1998, 61, 57.

14. Lacerda, L. D.; Pfeiffer, W. C.; Fiszman, M. Sci. Tot. Environm. 1987, 65, 163.

15. Barcellos, C.; Lacerda, L. D. Environm. Monitor. Assessem. 1994, 29, 183.

16. Mason, R. P.; Fitzgerald, W.F.; Hurley, J.P.; Hanson, A. K.; Donaghay, P. L.; Sieburth, J. M. Limnol. Oceanogr. 1993, 38, 1227.

17. Lacerda, L. D.; Gonçalves, G. O. Mar. Chem. 1999, 58 , in press.

18. Danziel, J. A. Mar. Chem.1992, 37, 171.

19. Danziel, J. A. Mar. Chem.1995, 49, 307.

20. Bloom, N.S.; Crecelius, E. A. Mar. Chem 1993, 14, 49.

21. McConchie, D.; Saenger, P.; Fawkes, R. Proc. Intern. Symp. Extraction and Processing for the Treatment and Minimization of Wastes, Queensland, 1996, 407.

22. Marins, R.V.; silva Filho, E. V.; Lacerda, L. D. J. Braz. Chem. Soc. 1996, 7, 177.

23. Mason, R. P.; Rolfhus, K. R; Fitzgerald, W. F. Water Air Soil Pollut. 1995. 80, 665.

24. Paraquetti, H. H. M.; Marins, R. V. Anais V Jornada Interna CETEM, Ser. Iniciação Científica 1997, 5, 46.

25. Mason, R. P.; O’Donnell, J.; Fitzgerald, W. F. In: C. Watras \& J. Huckabee (eds.), Mercury Pollution: Integration and Synthesis, Lewis Publ., Boca Raton, 1994, p: 83

26. Marins, R. V.; Lacerda, L. D.; Villas Boas, R. C. Mercury Contaminated Sites, Springer Verlag, Berlin, 1999, 273.

27. Krom, M. D.; Kaufman, A.; Hornung, H. Estuar. Coast. Shelf Sci. 1994, 38, 625. 